\title{
Polychlorinated biphenyls (PCB), UV radiation, and cutaneous malignant melanoma
}

\author{
Richard P Gallagher ${ }^{1 *}$, Tim K Lee ${ }^{1}$, Jean-Philippe Weber ${ }^{2}$, Alain Leblanc ${ }^{2}$, Marilyn Borugian ${ }^{1}$, J Mark Elwood ${ }^{1}$, \\ Amy C MacArthur ${ }^{1}$, Zenaida Abanto ${ }^{1}$, John J Spinelli ${ }^{1}$ \\ From 16th International Charles Heidelberger Symposium on Cancer Research \\ Coimbra, Portugal. 26-28 September 2010
}

Several older epidemiologic studies have suggested that exposure to polychlorinated biphenyls (PCBs) may increase risk of cutaneous malignant melanoma (CMM). These investigations, however, have not been able to control for sun exposure, and sun sensitivity, which are major risk factors for this cancer. We conducted a pilot study to examine the possible association between plasma levels of PCBs and risk of CMM, controlling for sun exposure and sun sensitivity.

Our case-control study compared levels of $14 \mathrm{PCB}$ congeners in the plasma of 80 Caucasian CMM patients, and 310 Caucasian controls frequency matched by age group and gender. Assays were conducted using gas chromatography and values were lipid-adjusted. Data concerning sun exposure history, sun sensitivity, and host pigmentation variables such as skin, eye and hair colour were also collected using standardized questionnaires. Odds ratios and 95\% confidence intervals were calculated for total PCBs, dioxin-like and non-dioxin like PCBs, as well as individual congeners using unconditional logistic regression.

A strong association was seen between melanoma risk and plasma levels of total PCBs, (OR highest quartile: 6.02; $95 \% \mathrm{CI}=2.00-18.17$ ); non-dioxin-like PCBs (OR highest quartile: $7.02 ; 95 \% \mathrm{CI}=2.30-21.43$ ); and many of the single congeners. These associations persisted after adjustment for recreational sun exposure, sun sensitivity and pigmentation factors.

Although the study results will require independent confirmation in larger case-control or cohort investigations, they suggest that potential environmental factors other than UV radiation may be involved in melanoma.

* Correspondence: rgallagher@bccrc.ca

${ }^{1}$ Cancer Control Research Program, BC Cancer Agency, Vancouver, Canada Full list of author information is available at the end of the article
Author details

${ }^{1}$ Cancer Control Research Program, BC Cancer Agency, Vancouver, Canada. ${ }^{2}$ Centre de Toxicologie, INSPQ, Quebec, Canada.

Published: 24 September 2010

\section{doi:}

Cite this article as: Gallagher et al:: Polychlorinated biphenyls (PCB), UV radiation, and cutaneous malignant melanoma. BMC Proceedings 20104 (Suppl 2):04.
Submit your next manuscript to BioMed Central and take full advantage of:

- Convenient online submission

- Thorough peer review

- No space constraints or color figure charges

- Immediate publication on acceptance

- Inclusion in PubMed, CAS, Scopus and Google Scholar

- Research which is freely available for redistribution

Submit your manuscript at www.biomedcentral.com/submit
C Biomed Central 